\title{
Numerical and Experimental Investigation of the Influence of External Wall Moisture on Building Temperature Distributions
}

\author{
Arkadiusz Urzędowski', Jacek Zaburko ${ }^{2 *}$, Piotr Gleń3 ${ }^{3}$ Grzegorz Łagód ${ }^{2}$ \\ 1 Faculty of Technology Fundamentals, Lublin University of Technology, ul. Nadbystrzycka 38, 20-618 \\ Lublin, Poland \\ 2 Faculty of Environmental Engineering, Lublin University of Technology, ul. Nadbystrzycka 40B, 20-618 \\ Lublin, Poland \\ ${ }^{3}$ Faculty of Civil Engineering and Architecture, Lublin University of Technology, ul. Nadbystrzycka 40, 20-618 \\ Lublin, Poland \\ * Corresponding author's e-mail: j.zaburko@pollub.pl
}

\begin{abstract}
In this paper, the authors made attempt to analyse the influence of moisture in the external wall of a building on the distribution of the temperature field, using numerical and experimental methods. Studies were carried out in the places of heat leakage occurring in structural joints of a single-family residential building, built in the traditional technology. In this study, the thermal bridge parameters were calculated by determining the values of thermal and moisture identifiers. For this purpose, two three-dimensional models of the building partition were designed based on an existing structure, and the boundary conditions for simulations were determined. The obtained heat flux values made it possible to perform quantitative calculations of heat flux distributions and temperatures of construction joints within the thermal bridge occurrence area. Moreover, the accuracy of the final temperatures obtained after combining the mathematical models with the values determined from thermograms was evaluated. In order to validate the results of numerical simulation, a test model was used taking into account the parameters specified in PL-EN 15026. The analysis aimed to present the handiness of using the simulation at the stage of planning the design and thermomodernisation of buildings in the places particularly exposed to adverse terrain and atmospheric conditions.
\end{abstract}

Keywords: CFD, CFX, heat transfer coefficient, wet building materials, thermal imaging, building structural materials, surface emissivity.

\section{INTRODUCTION}

The knowledge of physical processes resulting from the interaction of environmental factors on the building is the basis for the proper shaping of its microclimate $[1,2]$. The practical calculation methods, based on which the suitability of the applied building materials and structural solutions are assessed both in terms of thermal and humidity protection, gain particular significance here [3-5]. Rational estimation of humidity distribution in structural elements of building partitions is necessary to predict the scope and rate of progress of possible degradation processes. Wicking, damage to paint coatings and the appearance of microbiological efflorescence, mainly fungi, indicate the presence of a serious problem in the partitions $[1,6]$. In the $1950 \mathrm{~s}$, new buildings constructed in the contemporary technology did not contain external insulation and horizontal waterproofing, which resulted in the formation of numerous thermal bridges [7]. Adjacent elements with a much higher thermal conductivity coefficient caused large energy losses through point cooling of the partition. Increased, uncontrolled heat loss and lowering of the wall surface temperature are the most frequent reasons for exceeding 
the dew point temperature and condensation of water vapour in the wall. The result can be damage to the building, adverse indoor climate and increased unnecessarily high energy consumption [8]. This phenomenon also has many other negative consequences, and the high risk of wall moisture can cause serious damage to structural elements. Therefore, the knowledge of heat and moisture transport through building structures is increasingly important [9]. Bearing this fact in mind, it is important to analyse all the places that may lead to the formation of thermal bridges at the design stage, or the planned reconstruction or renovation. Reasonable estimation of the moisture distribution in the structural material is also a necessary factor to predict the extent and progress of degradation processes [10]. In the era of energy-efficient building technologies and popular thermal modernisation, increasingly thick insulation layers are often used to protect against wind but also against water vapour exfiltration, which contributes to increased concentrations of air pollutants and is an important source of moisture formation $[8,11]$.

The problems related to building physics in the field of heat and moisture transport, fluid dynamics and building mechanics are described by partial differential equations [3, 12-15]. Nowadays, there are many computer programs owing to which it is possible to present numerous phenomena occurring in building partitions using numerical simulations $[3,16]$. From the engineering point of view, the approach based on the use of mathematical model and finite element method is a practical solution to the problems of building physics $[6,11,12,14]$.

One of the methods to improve the energy standards of buildings is the use of thermal insulation of external walls [17]. However, depending on the construction technology of the structural layer, there is a risk of surface and interstitial condensation, so insulation with composites such as polystyrene, mineral wool or foam for existing buildings must be properly designed. Increased heat loss due to poorer energy balance results in higher energy consumption for heating and contributes to the risk of mould formation, making the indoor conditions uncomfortable to function in $[1,14,18]$. Moisture in the wall also affects the quality of the insulation, so one of the main tasks faced by the designer is to design a building envelope with some standard reserve so that it functions correctly under certain climatic conditions.
In the thermal and moisture calculations of the external partitions, one of the possible errors, committed at the stage of designing the thermal load, is neglecting the impact of thermal bridges on the transport of heat to the outside and the moisture of rooms. In order to determine the losses through the external partition, it is necessary to analyse it as a whole with particular attention to the connections of structural elements. Both thermal and moisture parameters can be determined by experimental analysis as well as numerical analysis. In this paper, the thermal bridge parameters of a construction joint were established by determining the values of thermal parameters, such as: heat flow rate, linear and branch transfer coefficient as well as humidity parameters, including: temperature distribution in the joint area, minimum temperatures on the internal surface of the partitions forming the bridge, and temperature factor $\mathrm{f}_{\mathrm{Rsi}}$.

Thermal bridges may cause the occurrence of a very dangerous phenomenon of dampness in walls, leading to a reduction in thermal comfort for users and, consequently, to the risk of fungal and mould growth. Unsightly changes on walls are difficult to remove, cause unpleasant odour in rooms and may lead to health problems such as allergies or respiratory infections.

The infrared imaging technique is useful for in situ analysis, because it allows the qualitative investigation to assess the causes of thermal bridges [19]. Typical thermal bridges are encountered at the junction of walls and ceilings despite the correct way of applying thermal insulation. These are areas of high thermal conductivity for which the thermal requirements of the partition are not met. The analyses of structures using thermographic techniques that describe the energy performance of a building and confirm the locations of the main heat losses were presented by Grinzato et al. [20], Albatici and Tonelli [21]. They defined a methodology to evaluate the thermal transmittance of an opaque component by infrared thermography based on the measurements of external and internal air temperatures, comparing the results of three cases with the data obtained from heat flow meters. The simulations using thermal imaging to determine thermal bridges were described by Zalewski et al. [22] and Asdrubali et al. [23]. For the study of structural thermal bridges and lowwear buildings using the finite element method in combination with infrared cameras were used in the studies of Heinrich and Dahlem [24] and Wrobel and Kisilewicz [25]. On the basis of literature 
data and the data collected during in-situ investigations using thermal imaging, the authors of this paper conducted a detailed analysis of the occurrence of the condensation problem in the corner of the room and at the wall-floor junction.

\section{MATERIALS AND METHODS}

\section{Building characteristics}

The analysed building is a one-storey, nonbasement single-family house with a usable attic, built between 1999 and 2003, located in the Lublin Province. The walls were erected in the traditional technology with $24 \mathrm{~cm}$ thick aerated concrete blocks insulated with a $12 \mathrm{~cm}$ layer of expanded polystyrene. The building is founded on footings, and the floor layer is a thermally insulated reinforced concrete slab on a sand bed. In this paper, two places of construction elements joints were considered, where the effects of longterm freezing and moisture transport phenomena within the analysed building partition were noticed (Figure 1):

- joint I, the corner, which is the connection of the ceiling with the curtain wall and the internal structural wall, separating the kitchen room and the unheated garage;

- joint II, a connection of the construction wall with foundation and floor on the ground.

Table 1 presents the physical properties of the materials of which joints I and II are composed. The material characteristics were determined based on the PN-EN ISO 12524:2004 [26] standard and tabulated data available in the literature. The material from which the walls are constructed is vapour-permeable, allowing for some degree of air transport as a result of the pressure difference outside and inside the building. The appearance of moisture is not necessarily the result of impaired thermal insulation but is often a symptom of capillary action. Out of the materials shown in Table 1, cellular concrete is the most vulnerable to moisture transport. The porous structure promotes the introduction of environmental water into the wall elements, significantly reducing the mechanical performance of the material, thus leading to a significant increase in heat loss through the damp partition [26]. The material properties defined in Table 1 will be used in the following discussion to parameterise the systems of equations.

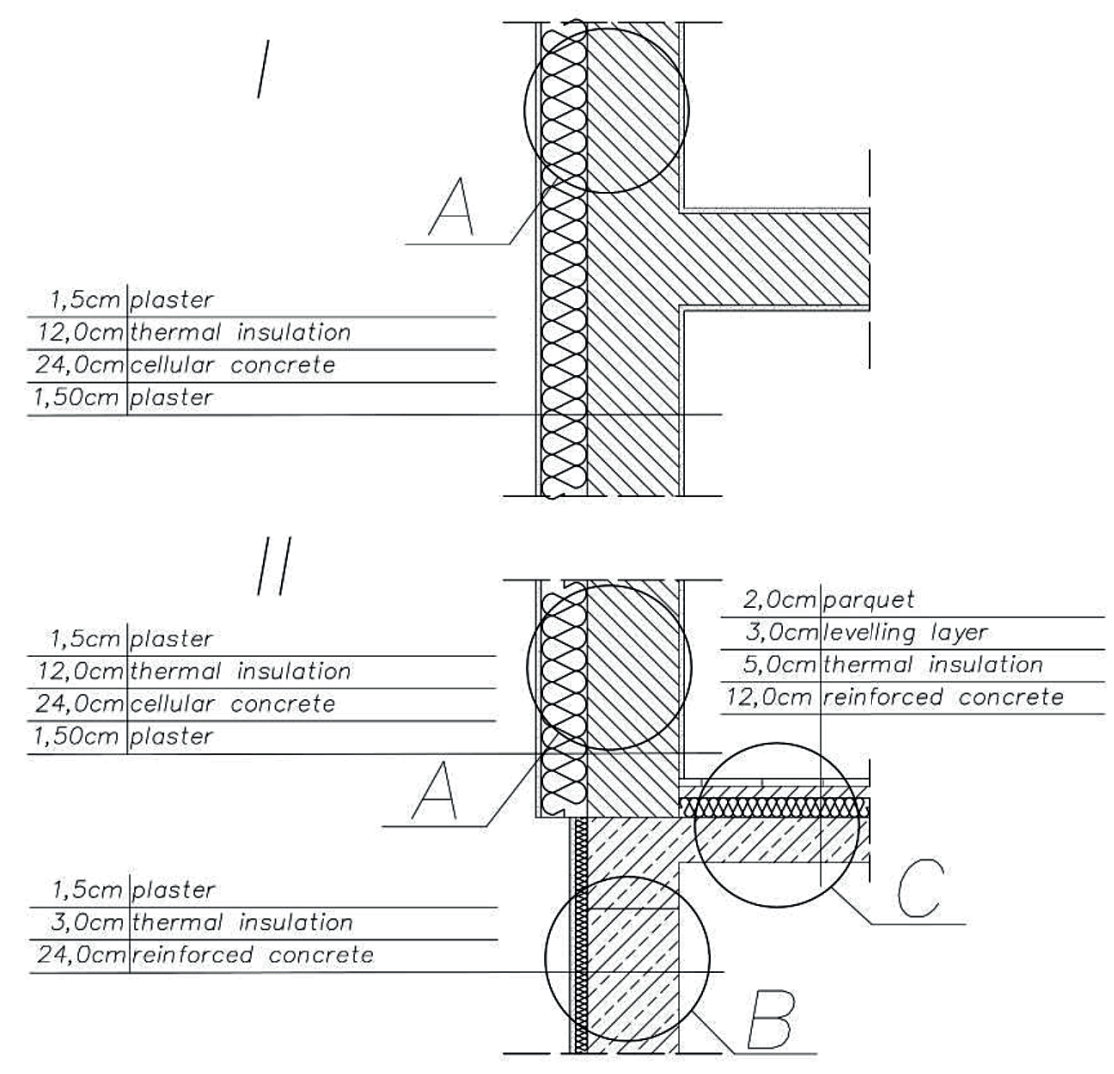

Fig. 1. Design of the analysed joints I and II 
Table 1. Physical properties of materials in the considered structural systems I and II

\begin{tabular}{|l|c|c|c|c|c|}
\hline \multirow{2}{*}{ Materials } & $\rho$ & \multicolumn{2}{|c|}{$\lambda$} & $\mathrm{c}$ & $\mu$ \\
\cline { 2 - 6 } & $\mathrm{kg} / \mathrm{m}^{3}$ & \multicolumn{2}{|c|}{$\mathrm{W} /(\mathrm{m} \cdot \mathrm{K})$} & $\mathrm{J} /(\mathrm{kg} \cdot \mathrm{K})$ & $10^{-4} \mathrm{~g} /(\mathrm{m} \cdot \mathrm{h} \cdot \mathrm{Pa})$ \\
\hline Plaster & 1850 & 0.82 & 0.90 & 0.84 & 45 \\
\hline Thermal insulation & 12 & 0.043 & 0.043 & 1.46 & 12 \\
\hline Cellular concrete & 700 & 0.25 & 0.30 & 0.84 & 180 \\
\hline Reinforced concrete & 2500 & 1.70 & 1.80 & 0.84 & 30 \\
\hline Levelling layer & 1900 & 1.00 & 1.10 & 0.84 & 200 \\
\hline Parquet & 800 & 0.22 & 0.26 & 2.51 & 300 \\
\hline
\end{tabular}

The authors determined heat transfer coefficient of a flat building characteristic of component consisting of thermally homogeneous layers, perpendicular to the heat flux, according to the equation [27]:

$$
U=\frac{1}{R_{s i}+R_{1}+R_{2}+\cdots+R_{n}+R_{s e}}
$$

where: $R_{1}, R_{2}, \ldots, R_{n}=\frac{d_{1}, d_{2}, \ldots, d_{n}}{\lambda_{1}, \lambda_{2}, \ldots, \lambda_{n}}-$ the design thermal resistance of each layer,

$R_{S i}, R_{S e}$ - heat transfer resistances on the inner and outer surface.

Joints I and II were divided into flat layered systems and described as A, B, C, respectively (Fig. 1). On the basis of the physical properties of the materials listed in Table 1, the heat transfer coefficient values for each system were determined and presented in Table 2. The obtained values were assigned to the materials in the computational fluid dynamics (CFD) software, the solver module of which performs finite element method (FEM) calculations. Among many tools available on the market, the authors have chosen the software for computer and numerical simulations - ANSYS - which allows solving equations describing fluid flow in porous media.

\section{Mathematical model of calculation}

Thermal studies of layered building partitions use the heat transport phenomenon described by the differential equation of unsteady heat conduction in solids - the Fourier-Kirchoff equation [28]:

$$
\frac{\delta T}{\delta t}=a \nabla^{2} T+\frac{1}{\rho c_{p}} \frac{\partial \lambda}{\partial T}=\left[\left(\frac{\delta T}{\delta x}\right)^{2}+\left(\frac{\delta T}{\delta y}\right)^{2}+\left(\frac{\delta T}{\delta z}\right)^{2}\right]+\frac{q_{v}}{\rho c_{p}}
$$

This expression for a constant heat transfer coefficient $(\lambda=$ const) and no internal heat sources $\left(q_{V}=0\right)$ assumes the form of Kirchoff's differential equation [28]:

$$
\frac{\delta T}{\delta t}=a \nabla^{2} T
$$

The subsequent stages of work were conducted in the Steady-State Thermal module, available in the Workbench 2020 R1 environment. The considered links were modelled using appropriate cut-out planes, in compliance with PN-EN ISO 10211 [29], according to which a building is divided into many parts, each forming a 3D or 2D geometric model. This model consists of a central element (core) and side elements. The authors used the Design Modeler editor to build them.

Boundary conditions were assumed, including the determination of heat transfer resistances on the partition surfaces and boundary temperatures. The values of design external temperature characteristic for the area in which the building is located, i.e. III climatic zone in Poland, equal to $t_{e}=-20^{\circ} \mathrm{C}[30]$ were assumed. For the rooms, the characteristic temperature for rooms intended for permanent stay of people without outer garments, not performing continuous physical work, $\mathrm{t}_{\mathrm{i}}=20^{\circ} \mathrm{C}$ was assumed. For the unheated room of the garage, separated by the structural wall from the kitchen (link I), $\mathrm{t}_{\mathrm{ig}}=10^{\circ} \mathrm{C}$ was assumed, while for the area under the floor on the ground (link II), $\mathrm{t}_{\mathrm{eg}}=-10{ }^{\circ} \mathrm{C}$ was assumed. These data were implemented into the models in the Engineering Data software environment. Discretization of the mesh was performed, the pitch step of which was $3 \mathrm{~cm}$, and after running the solver, the algorithm, applying the law of conservation of energy and Fourier's law, enabled the solution of a system of equations being a function of temperature at the nodes.

On the basis of the values of heat flux flowing through the joint obtained from simulations, the calculations of characteristic thermo-hygrometric parameters were performed: linear thermal coupling coefficient $\left.\mathrm{L}^{2 \mathrm{D}}[\mathrm{W} /(\mathrm{m} \cdot \mathrm{K}))\right]$, linear heat transfer 
Table 2. Determined values of thermal resistance and heat transfer coefficient for the considered layered partition systems

\begin{tabular}{|c|c|c|c|c|}
\hline & d & $\lambda$ & $\mathrm{R}$ & U \\
\hline & $\mathrm{m}$ & $\mathrm{W} / \mathrm{m}^{2} \mathrm{k}$ & $\mathrm{m}^{2} \mathrm{k} / \mathrm{W}$ & $\mathrm{W} / \mathrm{mK}$ \\
\hline \multicolumn{5}{|l|}{ A } \\
\hline $\mathrm{R}_{\mathrm{se}}$ & & & 0.040 & \\
\hline Plaster & 0.015 & 0.820 & 0.018 & \\
\hline Thermal insulation & 0.120 & 0.043 & 2.791 & \\
\hline Cellular concrete & 0.240 & 0.250 & 0.960 & \\
\hline Plaster & 0.015 & 0.082 & 0.183 & \\
\hline \multirow[t]{2}{*}{$\mathrm{R}_{\mathrm{si}}$} & & & 0.130 & \\
\hline & & & 3.992 & 0.251 \\
\hline \multicolumn{5}{|l|}{ B } \\
\hline $\mathrm{R}_{\mathrm{se}}$ & & & 0.040 & \\
\hline Plaster & 0.015 & 0.820 & 0.018 & \\
\hline Thermal insulation & 0.030 & 0.043 & 0.698 & \\
\hline Reinforced concrete & 0.240 & 1.700 & 0.141 & \\
\hline Plaster & 0.015 & 0.820 & 0.018 & \\
\hline \multirow[t]{2}{*}{$\mathrm{R}_{\mathrm{si}}$} & & & 0.130 & \\
\hline & & & 0.915 & 1.092 \\
\hline \multicolumn{5}{|l|}{ C } \\
\hline $\mathrm{R}_{\mathrm{se}}$ & & & 0.040 & \\
\hline Reinforced concrete & 0.120 & 1.700 & 0.071 & \\
\hline Thermal insulation & 0.050 & 0.043 & 1.163 & \\
\hline $\begin{array}{l}\text { Levelling layer } \\
\text { wyrównawcza }\end{array}$ & 0.030 & 1.000 & 0.030 & \\
\hline Parquet & 0.020 & 0.220 & 0.091 & \\
\hline \multirow[t]{2}{*}{$\mathrm{R}_{\mathrm{si}}$} & & & 0.170 & \\
\hline & & & 1.394 & 0.717 \\
\hline
\end{tabular}

coefficient $\psi[\mathrm{W} /(\mathrm{m} \cdot \mathrm{K})]$, branch heat transfer coefficient (concerning the appropriate part of the joint) $\psi_{\mathrm{g}}, \psi_{\mathrm{d}}[\mathrm{W} /(\mathrm{m} \cdot \mathrm{K})]$, the minimum temperature at the joint $\mathrm{t}_{\text {min. }}\left(\theta_{\text {si,min }}\right)\left[{ }^{\circ} \mathrm{C}\right]$ and temperature factor $\mathrm{f}_{\mathrm{Rsi}}$.

Figure 2 shows the results of a computer simulation that allows determining the value of the heat flux flowing through the joint. As a result of the performed analyses, the distribution of heat flux lines (adiabatic lines) was obtained. The temperature distribution in the joints indicates that the most exposed to freezing are the corners of the joints. In those places (marked with black circles), the temperature range with the highest values occupies the smallest volume of the whole joint, whereas the lowest values marked with blue colour reach deep inside the joint layers.

Both structures were analysed in terms of the distribution of heat fluxes and surface temperatures, but the paper presents the subsequent steps of determining the quantitative thermal and humidity parameters for joint II. For joint I, only the already determined values are given
(Table 3 ). Figure 3 shows the identifiers necessary for the calculations.

The value of the flux arriving at the wall from the inside consists of partial fluxes arriving at its upper and lower part. For this part, as a result of simulations $\Phi_{g 1}=20.332 \mathrm{~W}$ and $\Phi_{g 2}$ $=5.759 \mathrm{~W}$ were obtained, which after summing up gives $\Phi_{g}=26.091 \mathrm{~W}$. Similarly, the heat flux flowing to the bottom surface of the joint $\Phi_{d}$ was calculated, the value of which was $18.799 \mathrm{~W}$. On the basis of the obtained results, the total heat flux flowing through the joint was determined according to the formula [29]:

$$
\Phi=\Phi_{g}+\Phi_{d}=20.332+5.759=26.091 \mathrm{~W}
$$

The value of heat transfer coefficient concerning individual parts of the joint, according to Table 2, is $\mathrm{U}_{\mathrm{A}}=0.251 \mathrm{~W} / \mathrm{mK}, \mathrm{U}_{\mathrm{B}}=1.092 \mathrm{~W} /$ $\mathrm{mK}$. Linear thermal coupling coefficient (concerning the upper part of the joint): 

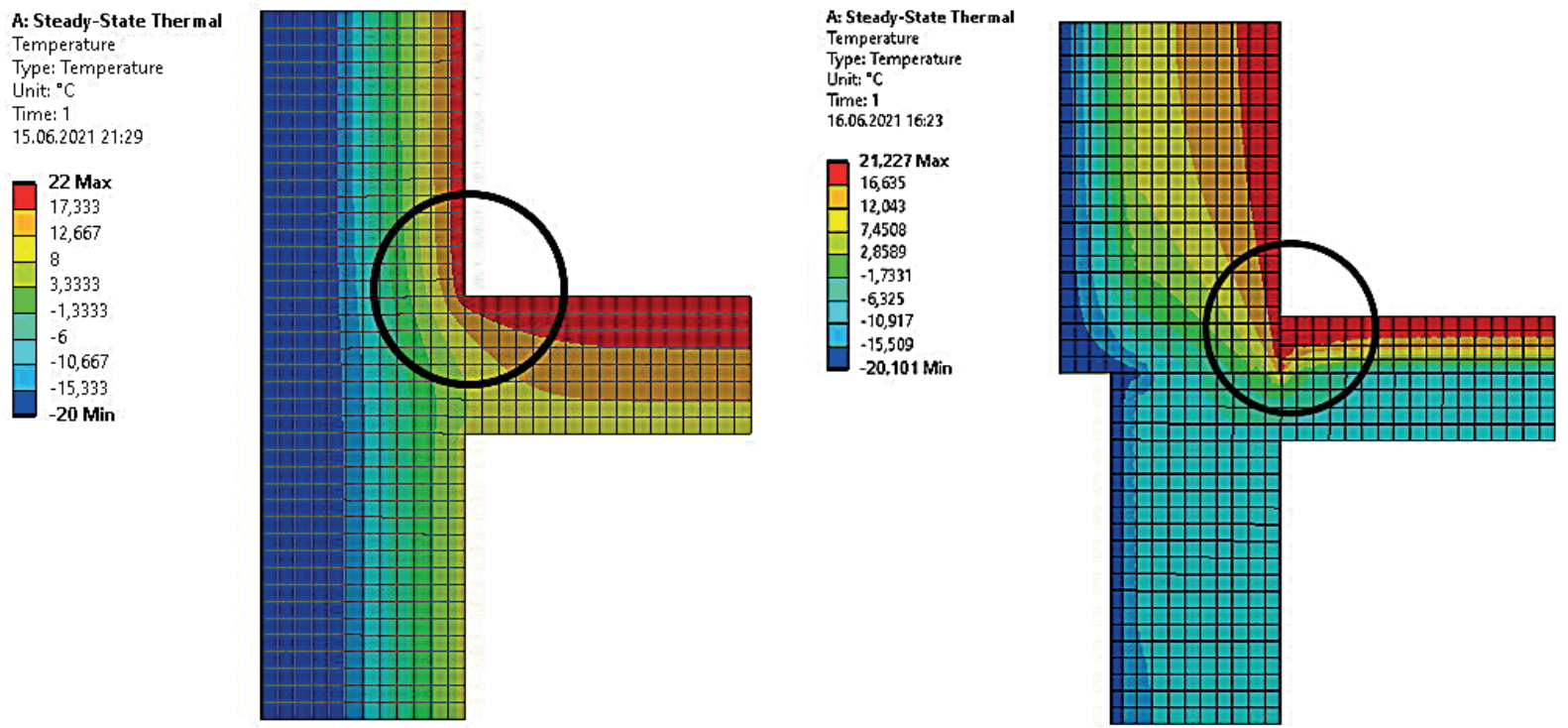

Fig. 2. Temperature distribution in analysed structural systems of joints I and II

Table 3. Quantitative thermal and moisture parameters determined for joints I and II

\begin{tabular}{|c|c|c|c|c|c|c|c|c|c|}
\hline Joint & $\Phi$ & $L_{g}{ }^{2 D}$ & $L_{d}^{2 D}$ & $\Psi_{\text {ig }}$ & $\Psi_{\text {id }}$ & $\Psi_{\text {eg }}$ & $\Psi_{\text {ed }}$ & $\Psi_{\mathrm{i}}$ & $\Psi_{\mathrm{e}}$ \\
\hline Joint I & 26.091 & 0.502 & 0.627 & 0.251 & -0.465 & -0.028 & -0.585 & -0.214 & -0.613 \\
\hline Joint II & 31.166 & 0.490 & 0.385 & 0.239 & 0.134 & 0.285 & 0.1 & 0.373 & 0.385 \\
\hline
\end{tabular}

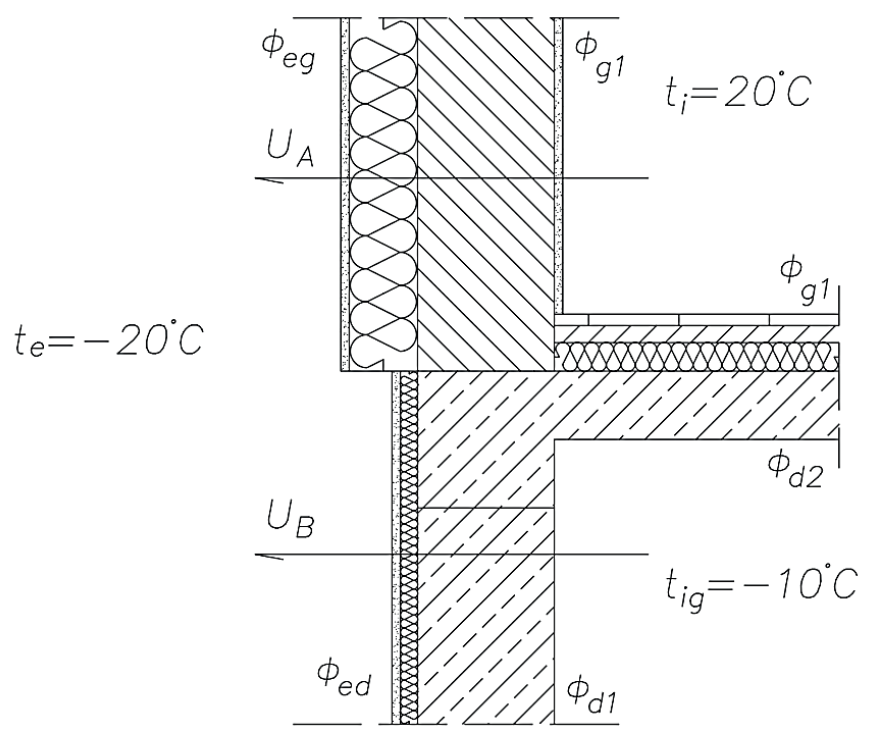

Fig. 3. Joint II with marked parameters describing the thermal characteristics

$$
L_{g}^{2 D}=\frac{\Phi_{g}}{l \cdot\left(t_{i}-t_{e}\right)}=\frac{20.091}{1 \cdot(20-(-20))}=0.502
$$

Branch heat transfer coefficient of the upper part of the joint (in internal dimensions)

$$
\Psi_{i g}=L_{g}^{2 D}\left(l_{i 1} \cdot U_{A}=0.502-(1.0 \cdot 0.251)=0.251\right.
$$

Linear thermal coupling coefficient (concerning the bottom of the joint):

$$
L_{d}^{2 D}=\frac{\Phi_{d}}{l \cdot\left(t_{i}-t_{i g}\right)}=\frac{18.799}{1 \cdot(20-(-10))}=0.627
$$


Branch heat transfer coefficient of the lower part of the joint:

$$
\Psi_{i d}=L_{d}^{2 D}\left(l_{i 2} \cdot U_{B}\right)=0.627-(1.0 \cdot 1.092)=-0.465
$$

Linear heat transfer coefficient of the entire joint (in internal dimensions):

$$
\Psi_{i}=\Psi_{i g}+\Psi_{i d}=0.251-0.465=-0.214
$$

Branch heat transfer coefficient of the upper part of the joint (in external dimensions):

$$
\Psi_{e g}=L_{g}^{2 D}\left(l_{e 1} \cdot U_{A}\right)=0.502-(1.11 \cdot 0.251)=-0.028
$$

Branch thermal transmittance of the lower part of the joint (in external dimensions)

$$
\Psi_{e d}=L_{d}^{2 D}\left(l_{e 2} \cdot U_{B}\right)=0.627-(1.11 \cdot 1.092)=-0.585
$$

Linear thermal transmittance of the entire joint (in external dimensions)

$$
\Psi_{e}=\Psi_{e g}+\Psi_{e d}=-0.028-0.585=-0.613
$$

The authors used a FLIR model 440bx camera to conduct a qualitative thermal imaging experiment. The study was conducted under winter conditions when the ambient temperature was $-1.4^{\circ} \mathrm{C}$ and the object was heated to about $20.5^{\circ} \mathrm{C}$. On the basis of PN-EN 13187 [19], the device was calibrated by setting the ambient temperature and the emissivity factor for cellular concrete. The purpose of this study was to analyse the temperature spectrum as a factor determining the temperature distribution of the wet wall.

\section{MEASUREMENT RESULTS AND DISCUSSION}

Quantitative thermal and moisture parameters were determined for joints and were presented in Table 3.

The obtained values of linear thermal transmittance coefficient are significantly lower than those indicative resulting from the norm PN-EN 14683:2017-09 [31]. For the foundation connection design solution adopted for joint II, the $\psi_{\mathrm{i}}$ value is $0.8 \mathrm{~W} / \mathrm{mK}$, while $\psi_{\mathrm{e}}=0.65 \mathrm{~W} / \mathrm{mK}$.

This is due to the fact that the modeling and analysis tools in the CDF environment allow taking into account the exact geometries of individual partition layers and assigning the actual physical values of the materials. Whereas lower values of the linear thermal transmittance coefficient in joint I result from the fact, that this connection is exposed to lower temperatures, especially on the ground side, with a thinner thermal insulation to the height of the floor layers.
The results of quantitative calculations carried out by the authors were compared with the results of the experimental tests performed with a thermal imaging camera. In accordance to PNEN ISO 13788 [5], the quantity characterizing the thermal quality of a building component and determining the risk of moisture occurrence is the temperature coefficient on the internal surface of the partition $f_{R s i}$ calculated from the relation:

$$
f_{R s i}=\frac{\theta_{s i}-\theta_{e}}{\theta_{i}-\theta_{e}}
$$

where: $\theta_{s i}-$ internal surface temperature $\left[{ }^{\circ} \mathrm{C}\right]$; $\theta_{e}-$ indoor air temperature $\left[{ }^{\circ} \mathrm{C}\right]$; $\theta_{i}-$ outdoor air temperature $\left[{ }^{\circ} \mathrm{C}\right]$.

Considering the assumptions of the standard procedure, the coefficient $f_{R s i, m i n}$ is determined for each month of the year. The month in which the temperature coefficient $f_{R s i \text { min }}$ has the highest value is the critical month (Table 4).

$$
f_{R s i, \min }=\frac{\theta_{s i, \min }-\theta_{e}}{\theta_{i}-\theta_{e}}
$$

The advantage of using the design temperature coefficient for determining the thermal quality is that the thermal performance is independent of the temperatures in a given location, providing a basis for reliable assessment of the risk of moisture. In properly designed partitions, the maximum value of the temperature coefficient $f_{R s i}$ should satisfy the condition:

$$
f_{\text {Rsi,min }}>f_{\text {Rsi.max }}
$$

The value of $f_{R s i \text { max }}$ was indicated as the highest value of $f_{R s i, m i n}$. 
Table 4. Calculation of temperature coefficient for each month from relation (14)

\begin{tabular}{|c|c|c|c|c|}
\hline Month & $\begin{array}{c}\theta^{\circ} \\
{\left[{ }^{\circ} \mathrm{C}\right]}\end{array}$ & $\begin{array}{c}\theta_{\text {si,min }} \\
{\left[{ }^{\circ} \mathrm{C}\right]}\end{array}$ & $\begin{array}{c}\theta_{\text {i }} \\
{\left[{ }^{\circ} \mathrm{C}\right]}\end{array}$ & $\mathrm{f}_{\text {Rsi,min }}$ \\
\hline I & -3.0 & 14.2 & 20 & 0.747 \\
\hline II & -1.6 & 14.7 & 20 & 0.755 \\
\hline III & 2.3 & 14.9 & 20 & 0.711 \\
\hline IV & 8.0 & 14.5 & 20 & 0.542 \\
\hline V & 13.0 & 14.8 & 20 & 0.261 \\
\hline VI & 16.7 & 16.0 & 20 & -0.216 \\
\hline VII & 18.0 & 17.5 & 20 & 0.259 \\
\hline VIII & 17.4 & 17.6 & 20 & 0.067 \\
\hline IX & 13.4 & 16.7 & 20 & 0.641 \\
\hline X & 8.5 & 15.9 & 20 & 0.749 \\
\hline XII & 3.7 & 15.9 & 20 & 0.780 \\
\hline XII & -0.5 & 15.5 & & 0.780 \\
\hline
\end{tabular}

Figure 4 shows a fragment of a joint between an external load-bearing wall and the floor in a room of the building analysed in the paper-joint II. The progressing biological corrosion has the form of salt efflorescence. The likely cause of this phenomenon is the capillary action of water through the foundation without waterproofing and the exposed, poorly insulated plinth around the building, which is a linear thermal bridge. The site was examined from the outside using the thermal imaging technology.

The moisture analysis of the partition nodes was based on the normative temperature measurement points read from the thermal imaging spectrum, summarised in Table 5 and Table 6.

Temperatures were used to assess the risk of moisture at the bridges: $\theta_{e}=-15^{\circ} \mathrm{C} ; \theta_{S i}=20^{\circ} \mathrm{C}$. On the basis of relation (14), $f_{R s i \text {,min }}$ was determined for the structural bridge: $f_{\text {Rsimin }}=\frac{\theta_{\text {si,min }}-\theta_{e}}{\theta_{i}-\theta_{e}}=\frac{1.4-(-15)}{20-(-15)}=0.469<f_{\text {Rsimax }}$

and a linear bridge:

$f_{R s i}=\frac{\theta_{\text {si,min }}-\theta_{e}}{\theta_{i}-\theta_{e}}=\frac{3.3-(-15)}{20-(-15)}=0.523<f_{\text {Rsi.max }}$

The temperature coefficient of the analysed nodes indicates that for the partition there is a risk of mould growth both in the outer and inner layer. On the basis of the thermogram, a point cloud defining the temperature distribution in the studied partition was extracted. A spreadsheet with a conditional formatting function was used to present the graphical result of the operation. For this purpose, the points with coordinates corresponding to the lowest temperature value in the partition were imported to the sheet. The temperature distribution for the structural bridge is shown in

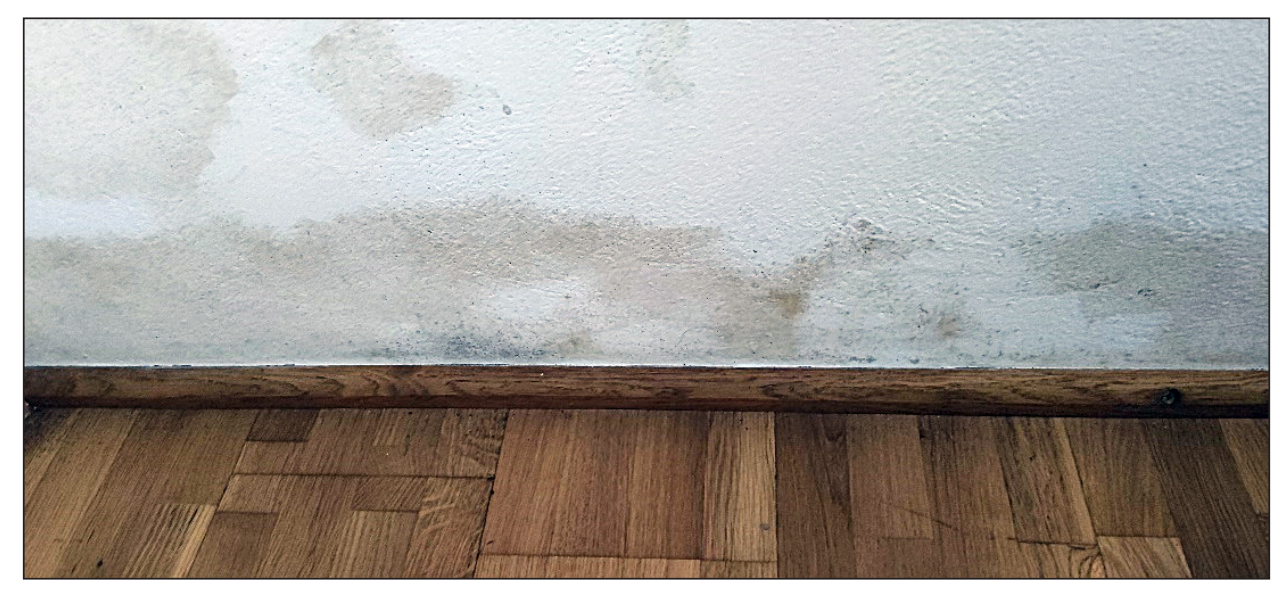

Fig. 4. The dampness of the curtain wall from the inside at the connection with the floor in the analysed object 
Table 5. Thermographic examination of joint I

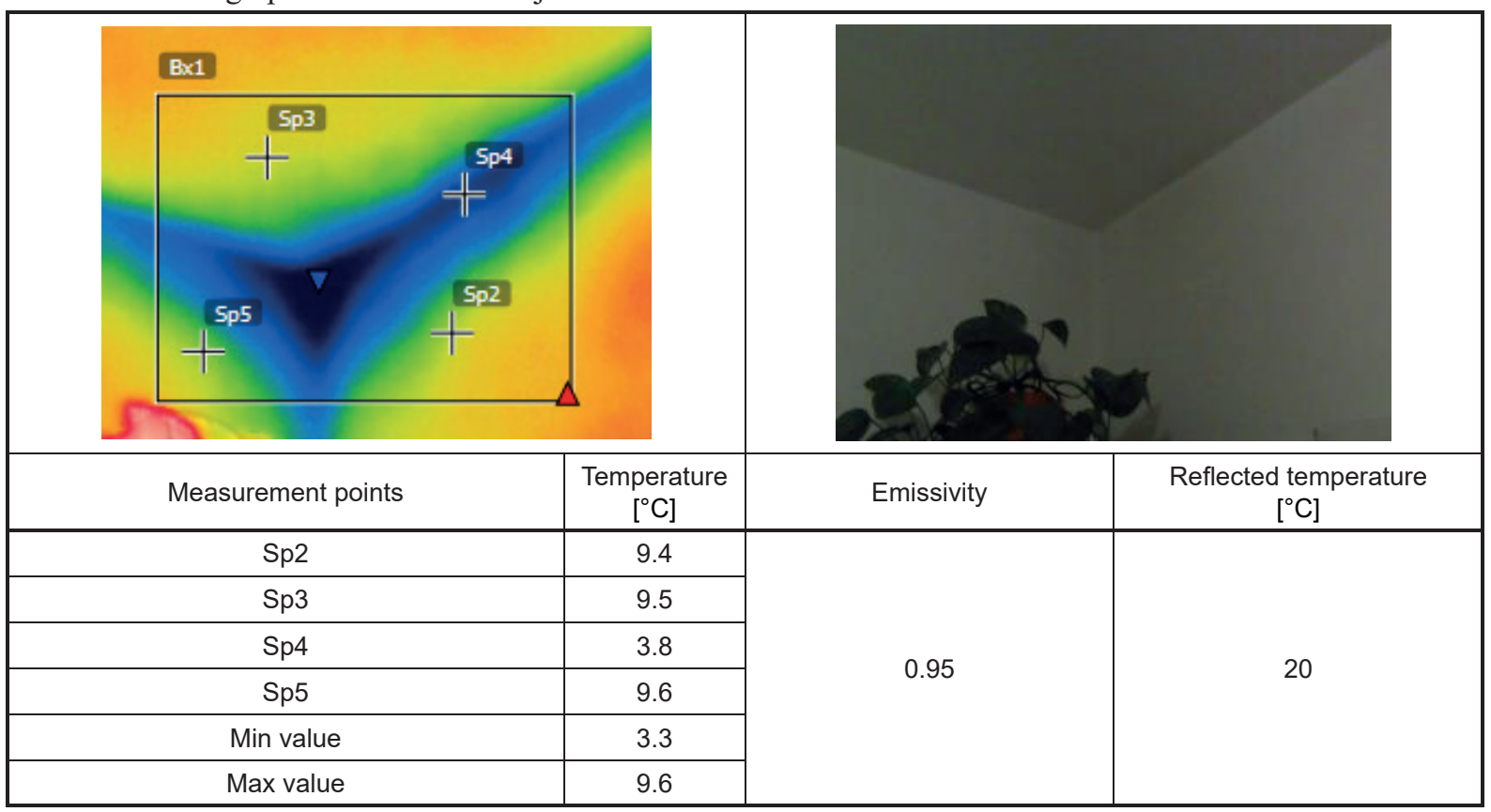

Table 6. Thermographic examination of joint II

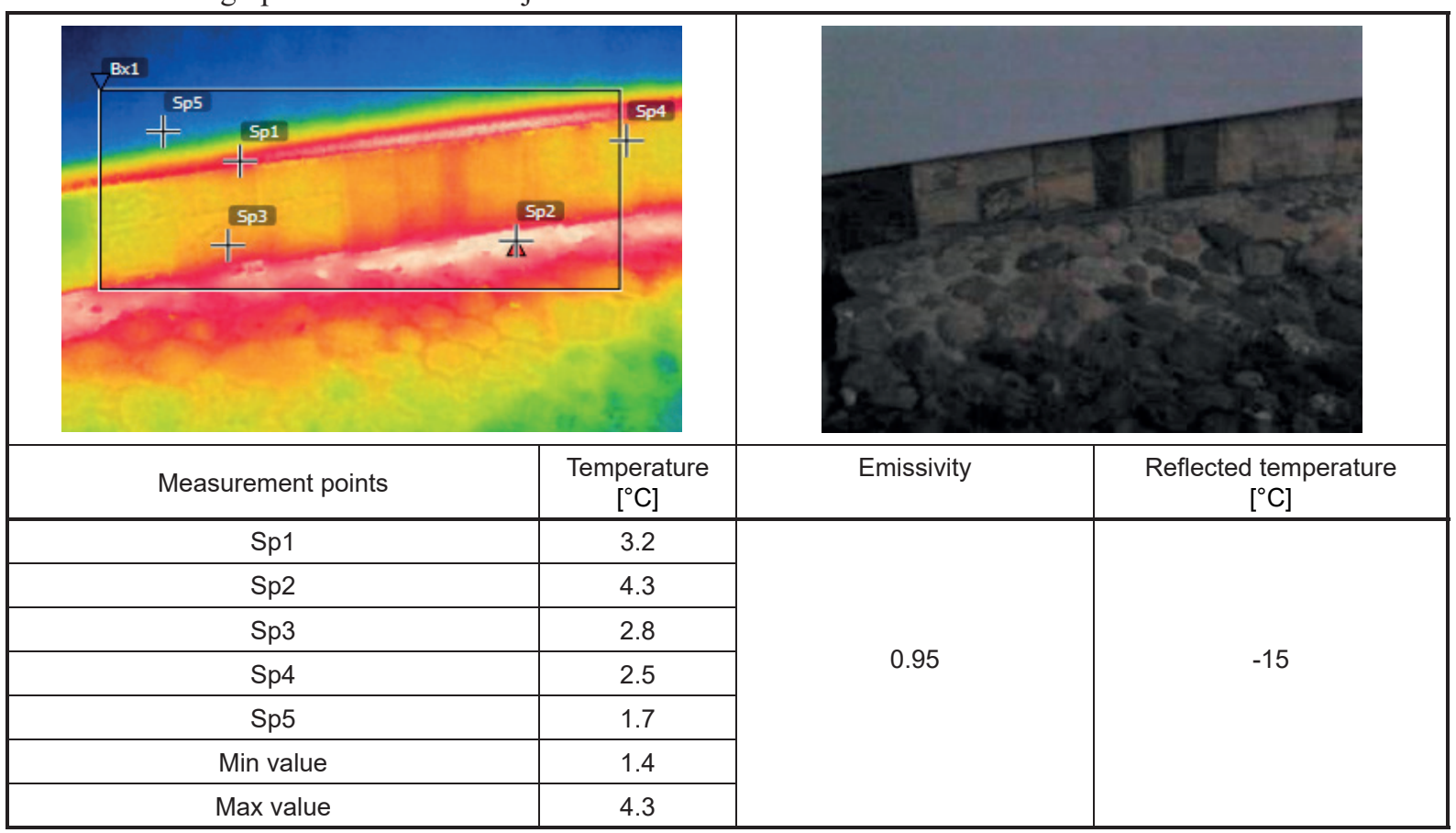

Figure 5. For a linear bridge, the temperature distribution is shown in Figure 6.

The colour of each cell represents the temperatures from the coordinates from the thermographic image. The boundary conditions for the building envelope simulation were assigned to the external surfaces of the model under varying conditions. The results of numerical calculations and measurements coincide, which confirms the usefulness of using simulations to graphically represent the temperature distribution in the analysed partition.

\section{CONCLUSIONS}

As a result of the simulation, the adiabat distribution have been designated, where can be 


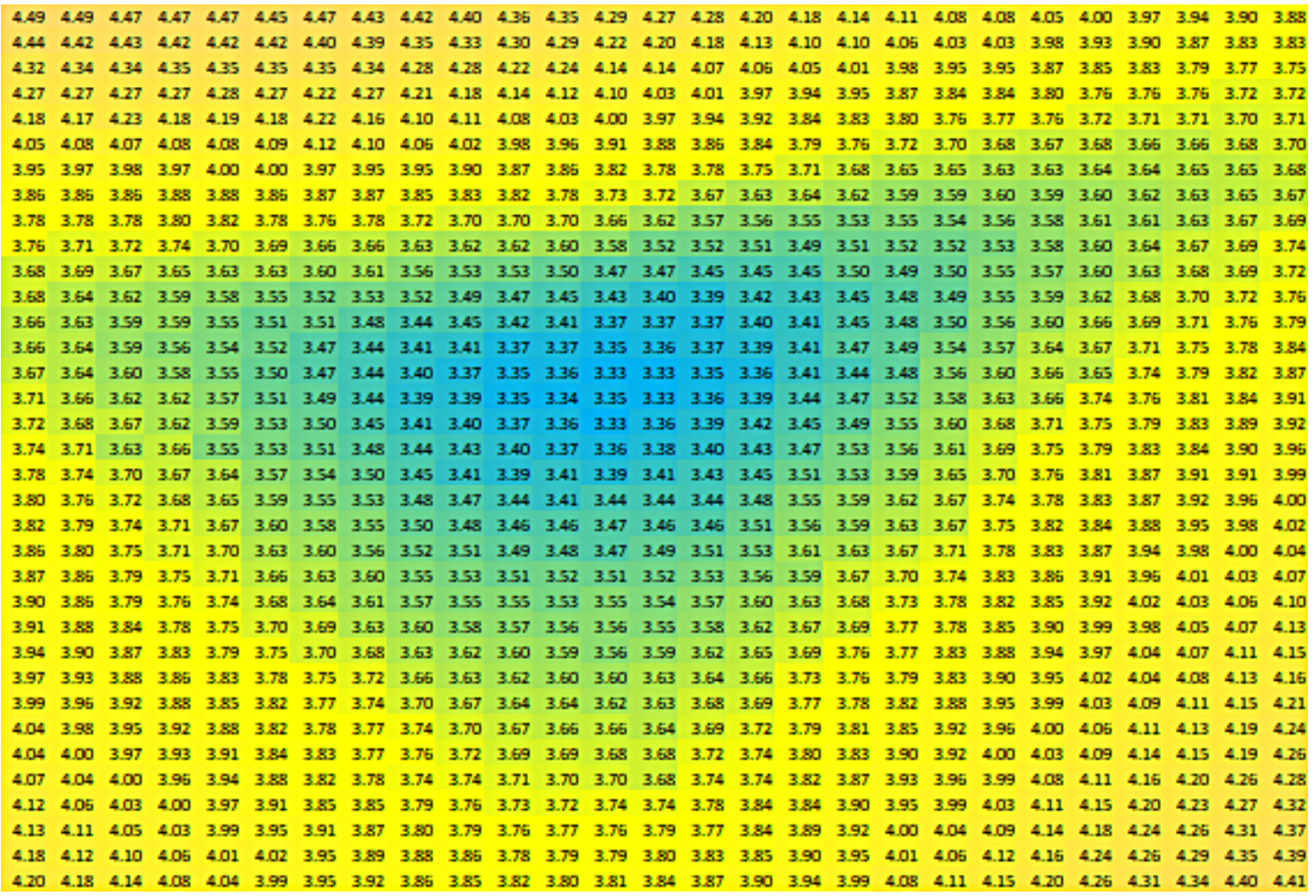

Fig. 5. Temperature distribution at the location of the structural damp barrier bridge

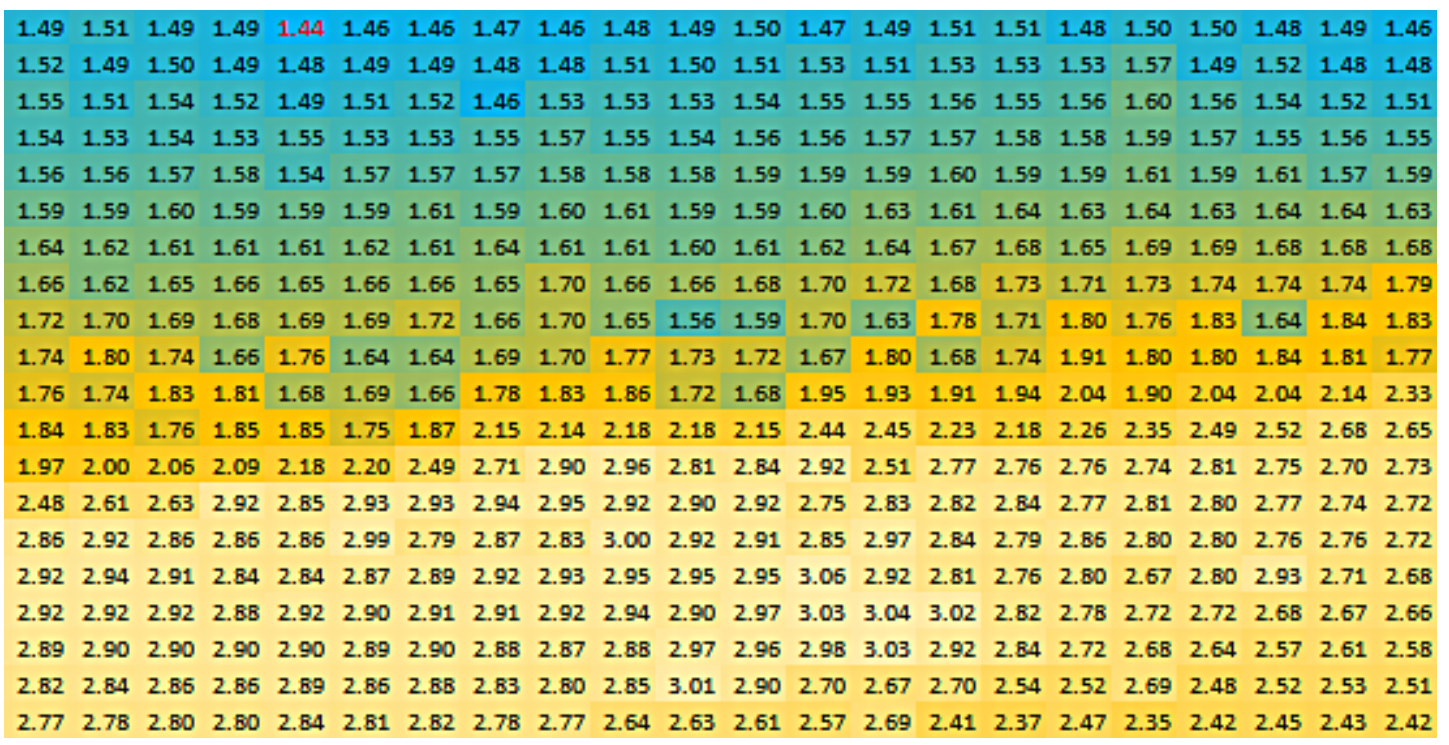

Fig. 6. Temperature distribution at the location of the linear bridge of the moist partition

read which parts of structural connections are most exposed to increased heat transport to the outside. There is a high probability of condensation in these places. The values of the thermal flux flowing onto the wall were also obtained from simulations, which allowed to initiate the linear and branch thermal coupling coefficient. In the joints, the values of the linear coefficient $\Psi$ are greater than those given in the standard
PN-EN ISO 12524:2003. It follows that using a simplified method or limited catalogues of thermal bridges, the designed investments are exposed to oversizing of heating needs. Therefore, it is worth verifying these calculations in existing buildings using the thermal imaging technique. However, these tests require a experience in interpreting the results and the defects can be detected only when the thermal resistance 
is sufficient to produce a visible thermal contrast. Further direction of research work will be thermal and moisture analyses of thermal bridges in other structural systems occurring in buildings, including historic ones.

\section{REFERENCES}

1. Garbacz M., Malec A., Duda-Saternus S., Suchorab Z., Guz L., Lagód G. Methods for early detection of microbiological infestation of buildings based on gas sensor technologies. Chemosensors 2020;8:7. DOI:10.3390/chemosensors8010007.

2. Suchorab Z., Sobczuk H., Guz, Łagód G. Gas sensors array as a device to classify mold threat of the buildings. Environ. Eng. V - Proc. 5th Natl. Congr. Environ. Eng., Taylor \& Francis Group, 6000 Broken Sound Parkway NW, Suite 300, Boca Raton, FL 33487-2742: CRC Press; 2017; 203-9. DOI:10.1201/9781315281971-28.

3. Sarkar K., Bhattacharjee B. Moisture distribution in concrete subjected to rain induced wetting-drying. Comput Concr. 2014;14:635-56. DOI:10.12989/ cac.2014.14.6.635.

4. PL-EN 15026 Hygrothermal performance of building components and building elements Assessment of moisture transfer by numerical simulation 2007;3:0-90.

5. PN-EN ISO 13788:2013-05 Cieplno-wilgotnościowe właściwości komponentów budowlanych i elementów budynku -- Temperatura powierzchni wewnętrznej konieczna do uniknięcia krytycznej wilgotności powierzchni i kondensacja międzywarstwowa -- Metody obliczania n.d.

6. Major M., Kosiń M. Modelowanie rozkładu temperatur w przegrodach zewnętrznych wykonanych z użyciem lekkich konstrukcji szkieletowych. Bud o Zoptymalizowanym Potencjale Energ 2016;18:5560. DOI:10.17512/bozpe.2016.2.08.

7. Orlik-Kozdoń B. Interior insulation of masonry walls-selected problems in the design. Energies 2019;12. DOI:10.3390/en12203895.

8. Suchorab Z., Frąc M., Guz Ł., Oszust K., Łagód G., GrytaA., et al.Amethod for early detection and identification of fungal contamination of building materials using e-nose. PLoS One. 2019;14:e0215179. DOI:10.1371/journal.pone.0215179.

9. Suchorab Z., Barnat-Hunek D., Sobczuk H. Influence of moisture on heat conductivity coefficient of aerated concrete. Ecol Chem Eng S. 2011;18:111-20.

10. Liu X., Chen Y., Ge H., Fazio P., Chen G. Numerical investigation for thermal performance of exterior walls of residential buildings with moisture transfer in hot summer and cold winter zone of Chi- na. Energy Build. 2015;93:259-68. DOI:10.1016/j. enbuild.2015.02.016.

11. StachniewiczR.Zapotrzebowanie na ciepło do ogrzewania budynku a zawilgocenie ścian zewnętrznych. Bud i Inżynieria Środowiska. 2012;3.

12. Suchorab Z., Łagód G. 3D Modeling of the Passive House. 2013;111.

13. Zimmerman W.B.J. Multiphysics Modeling with Finite Element Methods. 2006:432.

14. Isgor O.B., Razaqpur A.G. Finite element modeling of coupled heat transfer, moisture transport and carbonation processes in concrete structures. Cem. Concr. Compos. 2004;26:57-73. DOI:10.1016/ S0958-9465(02)00125-7.

15. van Schijndel A.W.M. Multiphysics modeling of building physical constructions. Build Simul 2011;4:49-60. DOI:10.1007/s12273-011-0020-0.

16. Hagentoft C-E., Kalagasidis A.S., Adl-Zarrabi B., Roels S., Carmeliet J., Hens H., et al. Assessment Method of Numerical Prediction Models for Combined Heat, Air and Moisture Transfer in Building Components: Benchmarks for One-dimensional Cases. J Therm Envel Build Sci 2004;27:327-52. DOI:10.1177/1097196304042436.

17. Firlag S., Piasecki M. NZEB renovation definition in a heating dominated climate: Case study of Poland. Appl Sci 2018;8:1605. DOI:10.3390/app8091605.

18. Künzel H.M., Holm A., Zirkelbach D., Karagiozis A.N. Simulation of indoor temperature and humidity conditions including hygrothermal interactions with the building envelope. Sol Energy. 2005;78:554-61. DOI:10.1016/j.solener.2004.03.002.

19. PN-EN 13187-2001 Właściwości cieplne budynków - Jakościowa detekcja wad cieplnych w obudowie budynku - Metoda podczerwieni 2001.

20. Grinzato E., Vavilov V., Kauppinen T. Quantitative infrared thermography in buildings. Energy Build 1998;29:1-9. DOI:10.1016/s0378-7788(97)00039-x.

21. Albatici R., Tonelli A.M. Infrared thermovision technique for the assessment of thermal transmittance value of opaque building elements on site. Energy Build. 2010;42:2177-83. DOI:10.1016/j. enbuild.2010.07.010.

22. Zalewski L., Lassue S., Rousse D., Boukhalfa K. Experimental and numerical characterization of thermal bridges in prefabricated building walls. Energy Convers Manag. 2010;51:2869-77. DOI:10.1016/j.enconman.2010.06.026.

23. Asdrubali F., Baldinelli G., Bianchi F. A quantitative methodology to evaluate thermal bridges in buildings. Appl Energy. 2012;97:365-73. DOI:10.1016/j.apenergy.2011.12.054.

24. Heinrich H., Dahlem K-H. Thermography of Low Energy Buildings 2000. DOI:10.21611/ qirt.2000.022. 
25. Wróbel A., Kisilewicz T. Thermographic detection of thermal bridges - aims, possibilities and conditions 2008. DOI:10.21611/qirt.2008.05_07_08.

26. PN-EN ISO 12524:2003. Materiały i wyroby budowlane. Właściwości cieplno-wilgotnościowe. Tabelaryczne wartości obliczeniowe.

27. Garbalińska H., Kosmaczewska-Możejko A. Badanie współczynnika sorpcji kapilarnej betonów komórkowych klas gęstości 400, 500, 600 i 700. Builder. 2020;275:16-8. DOI: $10.5604 / 01.3001 .0014 .1382$.
28. Wiśniewski S., Wiśniewski T.S. Wymiana ciepła. 2000.

29. Polish Standard PN ISO 6946. Komponenty budowlane i elementy budynku. Opór cieplny i współczynnik przenikania ciepła. Metoda obliczania. 2008: 1-30.

30. PN-EN ISO 10211:2008. Mostki cieplne w budynkach. Strumienie ciepła i temperatury powierzchni. Obliczenia szczegółowe 2008.

31. PN-EN ISO 14683:2017-09 Mostki cieplne w budynkach. Liniowy współczynnik przenikania ciepła. Metody uproszczone i wartości orientacyjne. 